\title{
The Self-Fashioning of Gentry Turncoats during the English Civil Wars
}

\author{
Andrew James Hopper
}

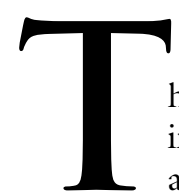

his article will investigate the striking phenomenon of side-changing during the English Civil War from the perspective of the defectors themselves as they sought to shape a respectable self-image for their contemporaries or posterity. Many explained away their former allegiance by depicting themselves as having arrived on the wrong side by accident, stratagem, or necessity. Choices of allegiance during the civil wars were not simply snap decisions of the summer of 1642. Many who took sides, reluctantly or not, subjected themselves to years of soul-searching thereafter. An examination of how gentry defectors fashioned their change in allegiance takes us to the heart of elite notions of loyalty, honor, and political identity. It also builds upon the growing interdisciplinary engagement with the self-fashioning of early modern elites. Literary scholars have pointed to an increased self-consciousness in contemporaries' letters and essays, while the urge toward autobiographical writing was often triggered by the traumatic experience of changing sides. ${ }^{1}$ Such self-reflection "certainly served some individuals as a means of easing tensions in their lives," and for some it became a balm for injured honor. ${ }^{2}$

The problem of choosing sides has long defied precise categorization, but historians now increasingly recognize that allegiance was not a fixed, unchanging matter but rather one that shifted and fluctuated. Although P. R. Newman dis-

\footnotetext{
Andrew James Hopper is a lecturer in history in the Centre for English Local History at the University of Leicester. He would like to thank Richard Cust and Jason Peacey for their valuable criticisms of this article, and he is obliged to Jason Peacey and Patrick Little for permission to cite their unpublished essays. $\mathrm{He}$ is also most grateful for the criticisms offered by members of the University of Oxford's Social, Cultural, and Economic History in the British Isles c. 1450-1750 Seminar and the University of Cambridge's Early Modern Economic and Social History Seminar, where earlier versions of this article were presented. He is also grateful to the editor and reviewers of this journal for their helpful comments.

${ }^{1}$ Ronald Bedford, Lloyd Davis, and Philippa Kelly, eds., Early Modern Autobiography: Theories, Genres, Practices (Ann Arbor, MI, 2006), 4-6; Muriel C. McClendon, Joseph P. Ward, and Michael MacDonald, eds., Protestant Identities: Religion, Society and Self-Fashioning in Post-Reformation England, (Stanford, CA, 1999), 12.

${ }^{2}$ Brigitte Glaser, The Creation of the Self in Autobiographical Forms of Writing in Seventeenth-Century England: Subjectivity and Self-Fashioning in Memoirs, Diaries, and Letters (Heidelberg, 1999), 14, 273.

Journal of British Studies 49 (April 2010): 000-000

(C) 2010 by The North American Conference on British Studies.

All rights reserved. 0021-9371/2010/4902-0007\$10.00
}

checked 1 
cussed several defections from a royalist perspective in his book The Old Service, there has been no monograph study of side-changing. ${ }^{3}$ The topic has been touched upon in the grand political narrative, such as the arrival of the three earls at Oxford in August 1643, or in biographical studies of notorious side-changers such as Sir Richard Grenville. ${ }^{4}$ Yet there is now a growing interest in the phenomenon. In 1994 Mark Stoyle argued that defectors met with derision, which suggests that "turncoats were the exception rather than the rule." While this is true in many cases, David Smith and Jason McElligott's recent collection on royalism has suggested that shifts in allegiance were more common than scholars realized. My research on Yorkshire, a county where turncoats were particularly prevalent, supports this assertion. ${ }^{6}$ Barbara Donagan has argued that varieties of royalism were so wide-ranging that they presented a "rainbow coalition" and that there was much common ground between moderates on both sides. ${ }^{7}$ The parliamentarian coalition was equally broad, and many felt closer to moderates among the enemy than the most zealous on their own side. Army officers on opposing sides maintained amicable correspondence, particularly as many were friends before the war. Many gentry on both sides also shared a political culture that was equally distrustful of popular insurgency and the royal excesses of the 1630s. Alongside a bipartisan code of soldierly honor and professional conduct, such shared ground, Donagan argues, "ameliorated relations between enemies." In an important recent monograph, Donagan has pointed out how this common gentry culture facilitated sidechanging. ${ }^{9}$

Older, traditional conceptions of honor stressed ancient lineage, blood, pedigree, outward display, and hunting. These ideas persisted alongside a more recent tradition that stressed virtue, education, sobriety, restraint, magistracy, godliness, and public service. ${ }^{10}$ Yet these traditions were not mutually exclusive, and they were often blended or appropriated for different purposes and audiences. Richard Cust has recently contended that, by the 1620 s, Renaissance humanism, classical republicanism, and English Calvinism had blended to generate an image of the virtuous, incorruptible "public man." Drawing upon the writings of the Stoics, such as Plutarch, Seneca, and Cicero, this political culture stressed virtue and constancy as paramount determinants of nobility. In theory, the gentry were sup-

${ }^{3}$ P. R. Newman, The Old Service: Royalist Regimental Colonels and the Civil War, 1642-46 (Manchester, 1993), 55-58, 118-25.

${ }^{4}$ Samuel R. Gardiner, History of the Great Civil War, 1642-1649, 4 vols. (London, 1987), 1: 199-202; Amos C. Miller, Sir Richard Grenville of the Civil War (London, 1979).

${ }^{5}$ Mark Stoyle, Loyalty and Locality: Popular Allegiance in Devon during the English Civil War (Exeter, 1994), 112.

${ }^{6}$ Andrew James Hopper, “'Fitted for Desperation': Honour and Treachery in Parliament's Yorkshire Command, 1642-1643," History 86, no. 2 (April 2001): 138-54.

${ }^{7}$ Jason McElligott and David L. Smith, "Introduction: Rethinking Royalists and Royalism," 4, and Barbara Donagan, "Varieties of Royalism," 68-71, both in Royalists and Royalism during the English Civil Wars, ed. Jason McElligott and David L. Smith (Cambridge, 2007).

${ }^{8}$ Barbara Donagan, "The Web of Honour: Soldiers, Christians, and Gentlemen in the English Civil War," Historical Journal 44, no. 2 (June 2001): 365.

${ }^{9}$ Barbara Donagan, War in England, 1642-1649 (Oxford, 2008), 278.

${ }^{10}$ Richard Cust, "Honour and Politics in Early Stuart England: The Case of Beaumont v. Hastings," Past and Present, no. 149 (November 1995): 60; Mervyn James, English Politics and the Concept of Honour, 1485-1642, Past and Present, suppl., no. 3 (1978), 92.

Thursday Dec 312009 09:46 AM JBS v49n2 85 BBS 
posed to refrain from private interests to prioritize their duty to serve the public. ${ }^{11}$ Brought up under such circumstances, it was clearly problematic for gentlemen to change sides without impugning their honor. Edward, earl of Clarendon, elucidated this by arguing that few turncoats prospered in their new allegiance: "We scarce find, in any story, a deserter of a trust or party he once adhered to, to be prosperous, or in any eminent estimation with those to whom he resorts . . . neither hath it been in the power or prerogative of any authority to preserve such men from the reproach and jealousy and scandal that naturally attend upon any defection." 12 Penetrating how turncoats sought to circumvent such difficulties might contribute much to the historiography on rhetoric, self-fashioning, and honor among the notoriously status-obsessed English gentry. ${ }^{13}$

The archival sources for studying the self-representation of gentry turncoats are scattered but plentiful. Many wrote letters to justify their side-changing to friends and contemporaries or corresponded with enemy officers in attempts to coordinate defections. Extensive legal notes survive from trials of recaptured turncoats, such as Sir John Hotham and Colonel John Morris, providing insights into how they defended their actions. ${ }^{14}$ The Hotham papers are currently being edited for publication and contain plentiful material relating to the trials of both father and son. Particularly rich sources are the memoirs of turncoats such as Sir Hugh Cholmley. ${ }^{15}$ Seeking to defend reputations for posterity, the memoirists were prone to selective memory as they set about constructing how they wished to be remembered by family and friends. There are also the several thousand cases dealt with by the Committee for Compounding. ${ }^{16}$ This committee set composition fines for royalists to pay to free their estates from sequestration. Cases before this committee included parliamentarians ordered to pay fines for their former royalism. Their petitions provide a further source, once allowance is made for their shaping by legal counsel and committee procedure. They naturally minimized the royalism of their earlier careers. For example, Thomas Simpson of Bishop Auckland petitioned that he had spent over $£ 400$ in raising his troop for Parliament in 1644, but he played down his earlier royalism as short-lived and forced on him for refusing to pay royalist taxes. His conversion narrative recounted his escape from hanging by the royalists, and this was endorsed by his parish minister and the

\footnotetext{
${ }^{11}$ Richard Cust, "The 'Public Man' in Late Tudor and Early Stuart England," in The Politics of the Public Sphere in Early Modern England, ed. Peter Lake and Steven Pincus (Manchester, 2007), 119, 126, 129.

${ }^{12}$ W. Dunn Macray, ed., The History of the Rebellion and Civil Wars in England begun in the year 1641 by Edward, Earl of Clarendon, 6 vols. (Oxford, 1888), 3:248-49.

${ }^{13}$ Richard Cust, "Catholicism, Antiquarianism and Gentry Honour: The Writings of Sir Thomas Shirley," Midland History 23 (1998): 40-70, and "Honour and Politics in Early Stuart England"; Donagan, "The Web of Honour."

${ }^{14}$ Legal defense of Sir John Hotham, c. November 1644, Hull History Centre, Hull University Archives (HHC: HUA), Hotham MS, DDHO/1/35; The trial of Colonel John Morris, 16 August 1649, British Library (BL), Egerton MS 1048, fols. 101-4.

${ }^{15}$ Jack Binns, ed., Memoirs and Memorials of Sir Hugh Cholmley of Whitby, 1600-1657, Yorkshire Archaeological Society, record ser., 153 (2000).

${ }^{16}$ Mary Anne Everett Green, ed., Calendar of the Committee for Compounding (Domestic), 1643-1660, 4 vols. (London, 1889).
}

Thursday Dec 312009 09:46 AM JBS v49n2 85 BBS 
parliamentarian officers Ferdinando, Lord Fairfax, and Colonel Francis Wren. Yet, despite this impressive effort, he was still fined $£ 50$ to discharge his estates. ${ }^{17}$

This article will first explore contemporary notions of side-changing and what it entailed and then discuss the self-representation of several professional army officers who deserted Parliament for the king during the early stages of the first civil war. It will go on to examine the significance of print culture in the representation of turncoats and then analyze in two case studies the self-fashioning of Sir Hugh Cholmley and the Hothams, governors of Hull.

Before the civil wars, most English notions of changing sides during wartime entailed changing one's religion. This view was nurtured by a popular and influential literary genre of printed accounts that claimed to represent the confessions of former British Catholics who had converted to Protestantism. ${ }^{18}$ Robin Clifton has argued that these tracts vulgarly pandered to Protestant prejudices about the superstitious nature of Catholicism and "were presented as lively and truthful accounts of the enemy camp written by men familiar with its workings." 19 Subsequent propaganda narratives of civil war turncoats built on this tradition, fulfilling a similar function by maligning the side they had deserted. Notions of side-changing were also informed by the realities of continental warfare. During the French Wars of Religion, Catholic aristocrats placed prices on the heads of their Protestant counterparts, thereby encouraging Protestant soldiers to change sides and murder their own commanders. The sieur de Maurevert, who shot Admiral Coligny in 1572, had changed sides three years earlier, shooting his Huguenot captain in the back as he did so. ${ }^{20}$ Changing sides might entail abandoning Christianity entirely. Approximately eight thousand British captives were seized by Barbary corsairs in the early seventeenth century, and large numbers of them apostatized and defected to Islam. ${ }^{21}$ Anxieties were voiced from the Privy Council to the theatre that Christians so enslaved would turn "renegado" and become Muslims. Robert Daborne and Philip Massinger wrote plays depicting such renegades as violently quarrelsome and treach-

\footnotetext{
${ }^{17}$ The case of Thomas Simpson of Newton Capp, Bishop Auckland, co. Durham, June 1646, The National Archives (TNA): Public Record Office (PRO), State Papers (SP) 23/181/361-77.

${ }^{18}$ Peter Lake, "Anti-Popery: The Structure of a Prejudice," in Conflict in Early Stuart England: Studies in Religion and Politics, 1603-1642, ed. Richard Cust and Ann Hughes (Harlow, 1989), 98. Examples of accounts of change of religion include Richard Sheldon, The Motives of Richard Sheldon, Priest for his Just, Voluntary and Free Renunciation of Communion with the Bishop of Rome (London, 1612); John Gee, The Foot out of the Snare with a Detection of Sundry Late Practices and Impostures of the Priests and Jesuites in England (London, 1624); James Wadsworth, The English Spanish Pilgrime. Or, A New Discoverie of Spanish Popery, and Jesuiticall stratagems with the estate of the English Pentioners and Fugitives under the King of Spaines Dominions, and Elsewhere at this Present (London, 1630); Thomas Abernethie, Abjuration of Poperie, by Thomas Abernethie: Sometime Jesuite, but now Penitent Sinner, and an Unworthie Member of the True Reformed Church of God in Scotland (Edinburgh, 1638).

${ }^{19}$ Robin Clifton, "Fear of Popery," in The Origins of the English Civil War, ed. Conrad Russell (Basingstoke, 1973), 148-49.

${ }^{20}$ Roger B. Manning, Swordsmen: The Martial Ethos in the Three Kingdoms (Oxford, 2003), 69, 70, 77, 109; Stuart Carroll, Blood and Violence in Early Modern France (Oxford, 2007), 272.

${ }^{21}$ Linda Colley, Captives: Britain, Empire and the World, 1600-1850 (London, 2002), 49-50.
} 
erous apostates, while the poet Samuel Rowlands pronounced that God would punish renegades with damnation and death. ${ }^{22}$

Other pre-civil war assumptions suspected soldiers of fortune of being potential side-changers because of their mercenary motives. The stereotype of the harddrinking, dueling, and swearing professional officer forged in Germany during the Thirty Years War hardly inspired expectations of constancy. ${ }^{23}$ The multiple defections of these professional officers, or "swordsmen," soon after civil war broke out did little to undermine the stereotype. Mark Stoyle has argued that parliamentarians turned against these foreign officers because many of them defected to the king by $1643 .^{24}$ Many hearkened to Lord Brooke's view that "I had rather have a thousand or two thousand honest Citizens that can onely handle their Armes, whose hearts goe with their hands, than two thousand of mercinary Souldiers, that boast of their forraigne experience." ${ }^{25}$ John Aubrey later penned an account of the Croatian, Carlo Fantom, a notorious example of this process. With a penchant for fighting duels and raping women, Fantom allegedly declared: "I care not for your Cause: I come to fight for your halfe-crowne, and your handsome woemen: my father was a R. Catholiq; and so was my grandfather. I have fought for the Christians against the Turkes; and for the Turkes against the Christians."26 Civilians feared that such officers might import frightful continental practices into the English civil wars. The words turncoat and renegado, with the latter also implying apostasy, were in considerable use by the early seventeenth century, and both carried deeply negative connotations. The former was employed in John Foxe's Acts and Monuments by 1570 and on the stage in Thomas Middleton's Game at Chess by $1624 .{ }^{27}$ The civil wars made these terms more widespread, and defectors among the English gentry clearly did not wish to be associated with them.

Gentry turncoats may have acted to protect themselves, family, and estates, as well as to profit by victory, but most denied such self-interested motives. They faced popular suspicions that many soldiers sought to side with the strongest. For instance, in 1646, Welsh parliamentarians maintained that the royalist Colonel Howell Gwinne had declared upon the king's surrender: "Heigh God, heigh Devil, I will be for the stronger side. ${ }^{28}$ Such sentiments found frequent expression in newsbooks, the Per-

\footnotetext{
${ }^{22}$ Nabil I. Matar, "The Renegade in English Seventeenth-Century Imagination," Studies in English Literature, 1500-1900 33, no. 3 (Summer 1993): 489, 495; Philip Massinger, The Renegado, a Tragaecomedie. As it hath beene often acted by the Queenes Majesties Servants, at the Private PlayHouse in Drurye-Lane (London, 1630); Robert Daborne, A Christian Turn'd Turke: or, The Tragicall Lives and Deaths of the Two Famous Pyrates, Ward and Dansiker. As it hath beene publickly acted (London, 1612).

${ }^{23}$ Ian Roy, "Royalist Reputations: the Cavalier Ideal and the Reality," in McElligott and Smith, Royalists and Royalism during the English Civil Wars, 90, 104-5.

${ }^{24}$ Mark Stoyle, Soldiers and Strangers: An Ethnic History of the English Civil War (New Haven, CT, 2005), 95, 103-9.

${ }^{25}$ BL, Thomason Tract (TT) E90(27), A Worthy Speech made by the Right Honourable the Lord Brooke, at the election of his Captaines and Commanders at Warwick Castle, 26 February (London, 1643), 7.

${ }^{26}$ Oliver Lawson Dick, ed., Aubrey's Brief Lives (Harmondsworth, 1949), 193-94.

${ }^{27}$ J. A. Simpson and E. S. C. Weiner, eds., The Oxford English Dictionary, 20 vols. (Oxford, 1989), 18:710.

${ }^{28}$ P. R. Newman, Royalist Officers in England and Wales, 1642-1660: A Biographical Dictionary (London, 1981), 171.
}

Thursday Dec 312009 09:46 AM JBS v49n2 85 BBS 
fect Diurnall alleging in 1644 that many officers were "ready to subject themselves to every new Master their Maxime being to side with the strongest." ${ }^{29}$ In defiance of such suspicion, many gentry turncoats sought to "spin" their past actions to support a self-image of constancy, reliability, and untarnished honor. This article explores the ways they sought to accomplish this, whether through appealing to contemporaries in print or by penning their memoirs for posterity.

The early Stuart gentry self-consciously fashioned their public reputations, particularly through the manipulation of ritual, rhetoric, and print. They compared political activity to "ascending the stage" and worried about humiliation in the eyes of a "news-hungry public." 30 The civil wars amplified these concerns. Facilitated by a proliferation of cheap print, the cult of personality among rival commanders flourished, and officers on both sides became subjects of life narratives. ${ }^{31}$ Side-changers were victimized by printed character assassinations, which utilized the well-crafted insult typical of contemporary litigation over slander and defamation. Many gentlemen initiated prosecutions in the Court of Chivalry during the 1630s, demanding reparation for insults that slighted their honor. ${ }^{32}$ Terms such as base, knave, rascal, lying, stinking, cheating, scurvy, beggarly, and unworthy featured in these insults. During the 1640s, a deserted side would inflict these same insults upon its backsliders. Anxious to show that defectors did not prosper, propagandists sought to strip turncoat officers of their gentility. In extreme cases, this degradation became physically enacted when turncoat officers were manacled and hanged like plebeians; the unfortunate Colonel John Morris complained in 1649 that this "shame and dishonour" was more troublesome to him than losing his life. ${ }^{33}$ As well as implying a forfeiture of gentle status, the term turncoat became a powerful term of political abuse. In 1643 the Perfect Diurnall defamed the Recorder of Poole as "turncoat Mr Constantine," while in 1647, John Lilburne warned Sir Thomas Fairfax that he would not comply with Cromwell and Ireton's "turncoat Lordly interest." ${ }^{34}$ The war also rendered the term more prevalent in everyday conversations and legal disputes. For example, Henry Cholmley, the constable of Tunstall, North Yorkshire, was accused of berating his neighbors for supporting parliament, "calling them Turn Coats, saying they were not worthy to come into honest mens company." ${ }^{35}$

${ }^{29}$ BL, TT E256(12), A Perfect Diurnall of Some Passages in Parliament, 23-30 September (London, 1644), 486.

${ }^{30}$ Richard Cust, "Wentworth's 'Change of Sides' in the 1620s," in The Political World of Thomas Wentworth, Earl of Strafford, 1621-1641, ed. Julia Merritt (Cambridge, 1996), 64.

${ }^{31}$ Kevin Sharpe and Steven N. Zwicker, eds., Writing Lives: Biography and Textuality, Identity and Representation in Early Modern England (Oxford, 2008), 19-20.

${ }^{32}$ Richard P. Cust and Andrew J. Hopper, eds., Cases in the Court of Chivalry, 1634-1640, Publications of the Harleian Society, new ser., 18 (2006); Richard Cust and Andrew Hopper, "Duelling and the Court of Chivalry in Early Stuart England," in Cultures of Violence: Interpersonal Violence in Historical Perspective, ed. Stuart Carroll (Basingstoke, 2007), 156-74.

${ }^{33}$ Journal of the civil war by John Syms, July 1644, BL, Additional (Add.) MS 35297, fol. 38r; The trial of Colonel John Morris, 16 August 1649, BL, Egerton MS 1048, fols. 103-4.

${ }^{34}$ BL, TT E250(8), A Perfect Diurnall of Some Passages in Parliament, 4-11 September (London, 1643), 58; BL, TT E409(22), The Juglers Discovered, In Two Letters Writ By Lievt. Col. John Lilburne, Prerogative Prisoner in the Tower of London, l October (London, 1647), 4.

35 The information of Richard Fawcett of Richmond, August 1645, TNA: PRO, SP 23/172/ $450-459$

Thursday Dec 312009 09:46 AM JBS v49n2 85 BBS 
Side-changers sought to deflect such abuse by claiming political constancy for their actions. When the earl of Holland defected to the king in August 1643, he refused to apologize for his previous parliamentarianism or to admit any offense whatsoever. This refusal proved a major obstacle to his integration into the royalist cause despite his armed attendance at the first battle of Newbury. ${ }^{36}$ In November 1643, he returned to Parliament and published a tract to justify his return, in which he compared himself to rivers and streams: "Naturally are they inclined to revert, and to looke backe to their Channells, and long-kept course againe." ${ }^{37}$ When he was executed on 9 March 1649, for a second bout of armed royalism, he argued that he had always been faithful to Parliament, a remarkable claim for a man who had deserted them twice. Yet, for Holland, it was essential to craft a self-narrative of constancy to protect not only his self-regard but also his posterity. He argued that the cause, not he, had changed. He claimed, quite sincerely, that, "I have never gone off from those Principles that ever I have professed." ${ }^{38}$ Indeed, by 1649 Holland could claim greater constancy to Parliament's war aims of 1642 than the regicides, whom the majority of parliamentarians considered had perverted the cause. Holland constituted an extreme example of how this process left individuals vulnerable to the slur of being turncoats. As the parliamentarian coalition fractured in the later 1640s, there were many like him, left disenfranchised and unrepresented by a cause whose politics grew ever more radical.

In order to consolidate support in changing political circumstances, both sides resorted to political and religious oaths to bind supporters to them, minimize turncoating, and prevent backsliding. Yet the meanings of oaths of allegiance became more widely interpreted and contested, posing problems for those striving for political constancy. Royalists held that the traditional oaths of supremacy and allegiance were adequate for their supporters, but occasionally royalist generals imposed additional oaths upon people to oppose Parliament. ${ }^{39}$ In Oxford, the city's regiment swore an oath to defend the king. ${ }^{40}$ Parliamentarian propagandists vilified royalists for forcing oaths upon helpless prisoners, John Vicars blasting the "Oxonian Protestation or Covenant against the Parliament." ${ }^{41}$ However, the successive oaths Parliament imposed upon the people were much more far-reaching. Edward Vallance has argued that they met with equivocation in many quarters, not through political hostility, but because people feared forswearing themselves in an uncertain future or contradicting previous oaths. The first of these, the Protestation of 1641, pledged to protect the king's person, the privilege of Parliament, and the Protestant religion. From 1642, both sides interpreted this am-

\footnotetext{
${ }^{36}$ Macray, ed., The History of the Rebellion, 3:195.

${ }^{37}$ BL, TT E32(14): A Declaration made to the Kingdome by Henry, Earle of Holland, 10 February (London, 1644), 6.

${ }^{38}$ Barbara Donagan, "A Courtier's Progress: Greed and Consistency in the Life of the Earl of Holland," Historical Journal 19, no. 2 (June 1976): 348, 352.

${ }^{39}$ David Martin Jones, Conscience and Allegiance in Seventeenth-Century England: The Political Significance of Oaths and Engagements (New York, 1999), 112-13.

${ }^{40}$ Oath of the Oxford regiment, n.d., BL, Harleian (Harl.) MS 6852, fol. 22r.

${ }^{41}$ BL, TT E33(18): A Looking-glasse for Malignants: or, Gods Hand Against God-haters . . . by John Vicars (London, 1643), 23-24; Joshua Sprigge, Anglia Rediviva; Englands Recovery (London, 1647), 51.
}

Thursday Dec 312009 09:46 AM JBS v49n2 85 BBS 
biguity to their advantage. ${ }^{42}$ However, in districts where Catholic royalists were prominent, some parliamentarians turned on backsliders for breaking this oath. For example, in April 1643, Sir John Hotham accused his kinsman Sir Hugh Cholmley of "falsifying his Protestation" by his defection to the king and "revolting to the Popish army." Soon after, Sir George Chudleigh defended himself against similar charges. Despite making his peace with the king, Chudleigh's printed defense maintained that he had "done my utmost faithfully according to my Protestation." ${ }^{43}$ Parliament's second oath was the Vow and Covenant, administered from June 1643 in an attempt to isolate royalists and commit the people to war against the king. From October 1643, Parliament imposed a third oath, the Solemn League and Covenant, to pledge its supporters to a Scottish alliance and a Presbyterian church settlement. The earl of Holland took this Covenant as a means of reconciling himself with Parliament after returning from his first defection to the royalists in November $1643 .{ }^{44}$ On 5 February 1644, an ordinance directed that the Solemn League and Covenant should be taken by every adult male in England and Wales. ${ }^{45}$ Parish ministers were ordered to send lists of refusers to Parliament, although the strength of enforcement in the localities was patchy. ${ }^{46} \mathrm{It}$ was also pressed on royalist prisoners of war and those compounding for their estates. During the first civil war, most gentry defections to the king took place before the Solemn League and Covenant was in place, but the minority of turncoats who became royalists having previously taken the Covenant might face execution as oath-breakers. ${ }^{47}$ The parliamentary newsbook The Moderate declared, in August 1648, that any royalist who had previously taken the Negative Oath or the Covenant could be executed without mercy. ${ }^{48}$ Parliament had put to death many recaptured turncoats from 1643 , but this declaration was a violent reaction against the increasingly serious defections that threatened to reverse Parliament's victory in the first civil war. ${ }^{49}$ Recaptured turncoats, such as Colonels John Poyer and

\footnotetext{
${ }^{42}$ Edward Vallance, "Protestation, Vow, Covenant and Engagement: Swearing Allegiance in the English Civil War," Historical Research 75, no. 190 (November 2002): 408-11, 417-19.

${ }^{43}$ BL, TT E247(21): A Perfect Diurnall of the Passages in Parliament, 3-10 April (London, 1643); BL, TT E37(20), A Declaration Published in the County of Devon by that Grand Ambodexter, Sir George Chudleigh Baronet (London, 1644), 3.

${ }^{44}$ Some royalists had wanted an oath of allegiance imposed upon Holland after his arrival at Oxford, and when he returned to parliament, Holland had to declare that he had taken no royalist oath: Macray, The History of the Rebellion, 3:146-47; Parliamentary journal of Sir Simonds D'Ewes, BL, Harl. MS 165, fols. 227v-228r; BL, TT E32(14), A Declaration made to the Kingdome by Henry, Earle of Holland, 3 .

${ }^{45}$ Journals of the House of Lords, 6:411.

${ }^{46}$ Jones, Conscience and Allegiance in Seventeenth-Century England, 130.

${ }^{47}$ Charles Carlton, Going to the Wars: The Experience of the British Civil Wars, 1638-1651 (London, 1992), 198.

${ }^{48}$ The Negative Oath was required of compounding royalists from April 1645 and involved a pledge not to assist the king in the war and to submit to Parliament: Jones, Conscience and Allegiance in Seventeenth-Century England, 115; BL, TT E461(16), The Moderate Impartially Communicating Martial Affaires to the Kingdome of England, 22-29 August (London, 1648); Robert Ashton, Counter Revolution: The Second Civil War and Its Origins, 1646-48 (New Haven, CT, 1994), 400.

${ }^{49}$ Donagan, War in England, 319 n. Executions of recaptured turncoats began when Reading was surrendered to the earl of Essex in April 1643. Parliamentarians hanged more recaptured turncoats in Devon during 1644 and 1645: Donagan, War in England, 104, 176; Ian Gentles, The English Revolution and the Wars in the Three Kingdoms, 1638-1652 (Harlow, 2007), 170; Journal of the civil war by John Syms, 1642-1649, BL, Add. MS 35297, fols. 38r, 47r, 61r; Stoyle, Loyalty and Locality, 112.
}

Thursday Dec 312009 09:46 AM JBS v49n2 85 BBS 
John Morris, were shot or hanged, while other condemned defectors, such as Major-General Rowland Laugharne, Colonel Rice Powell, and Lieutenant-Colonel Henry Farr, were extremely fortunate to be spared. ${ }^{50}$ Yet, the executions of turncoat officers in 1648 were for betraying their trust rather than for breaking the Covenant. Parliamentarians were uncomfortably aware that the Covenant required its takers to preserve the king's person, a pledge which defectors in 1648 could forcefully argue that Parliament had broken. So, despite their contested nature, claims to political constancy would be arbitrated by the victors of the second civil war as factional politics at Westminster came to define and determine who would be stigmatized as turncoats and oath-breakers.

This article will now examine the self-representations of the professional army officers who deserted Parliament for the king during the early stages of the first civil war. Most of these officers claimed that they had never intended to participate in rebellion. Although this seems suggestive of royalist propaganda, it remains persuasive because, until September 1642, it was doubtful if civil war was possible owing to the king's failure to recruit an army capable of facing the earl of Essex. Officers who had enlisted in Parliament's army for Ireland found themselves channeled into Essex's army, and their terms of service changed without consultation. This prompted several high-profile incidents of turncoating, beginning with the spectacular defection of Sir Faithful Fortescue's troop to the royalists during the Battle of Edgehill. Raised in summer 1642, this troop was intended for Ireland, and Fortescue could reasonably argue that it had never been his intention to oppose the king's person on an English battlefield. He became a committed royalist thereafter and fought at Worcester in $1651 .{ }^{51}$ Another defector from the army for Ireland became the civil wars' most notorious multiple turncoat. Sir John Urry, a Scotsman with continental military experience, was often depicted as the classic example of the professional whose own interests outweighed service to either side. His cornet adopted the motto of Francesco Sforza, Duke of Milan: "Nemo me impune lacessit" (No one attacks me with impunity). ${ }^{52}$ This motto suggests an aggressive attachment to his martial honor. Nevertheless, when Urry defected in June 1643, he carefully "professed repentance for having been in rebellion," probably through concern that his low rank slighted his reputation. He was then "magnified and extolled" at Oxford, where he was commissioned and knighted. Importantly, Urry sought to protect himself from charges of betraying trust by resigning his parliamentarian commission a month before he defected. He also claimed to have refused an oath not to enter royalist service. ${ }^{53}$ Although Urry's successful negotiation of his defection owed something to professional codes of conduct, it was more firmly

\footnotetext{
${ }^{50}$ Ashton, Counter Revolution, 406, 421, 465-66.

${ }^{51}$ Basil Morgan, "Sir Faithful Fortescue (b. in or before 1581, d.1666)," in The Oxford Dictionary of National Biography (Oxford, 2004) (ODNB); Newman, The Old Service, 57-58, and Royalist Officers, 142; Macray, The History of the Rebellion, 2:360, 363.

${ }^{52}$ Ian Gentles, "The Iconography of Revolution: England, 1642-1649," in Soldiers, Writers and Statesmen of the English Revolution, ed. Ian Gentles, John Morrill, and Blair Worden (Cambridge, 1998), 100.

${ }^{53}$ Macray, The History of the Rebellion, 3:55, 58.
} 
grounded in his potential usefulness to the royalist cause. ${ }^{54}$ Despite his precautions, many speculated on whether he would change sides again, which he did, so often that he was later commonly described as "of turncoat memory." 55

Another defector who returned from Irish service was James Chudleigh of Ashton, county Devon. Clarendon recalled that Chudleigh had originally offered his services to the king in December 1642 but that he had been rebuffed because of his parliamentarian family and his part in revealing the Army plot of 1641. ${ }^{56}$ London propagandists praised Chudleigh's "immortal Fame," for "his discreet and valient carriage" against the Cornish, and he was appointed sergeant-majorgeneral to the earl of Stamford's parliamentarian army in the west. ${ }^{57}$ After a series of engagements, Chudleigh was eventually captured at the battle of Stratton on 16 May 1643. The royalists maintained that he changed sides several days later, but parliamentarians claimed that Chudleigh had defected during the battle itself. This enabled Stamford to divert attention from his own ignominious flight to reproach Chudleigh's treachery for the defeat. Chudleigh's self-regard did not take kindly to such treatment; his military reputation had hitherto been promoted in print by boastfully exaggerating his successes while blaming others for reverses. ${ }^{58}$ Hoping to utilize Chudleigh's example to provoke further defections, the royalist press at Oxford printed his self-defense. The tract blended Chudleigh's fiery indignation with personal attacks on Devon parliamentarians to fashion his defection as motivated entirely by conviction. Chudleigh maintained that his captors treated him honorably and that their commanders persuaded him that the royalist cause was just. He argued that his new Cornish gentry friends were more inclined to peace than those he termed "the factious Tumult of the Citty of Exeter," who maintained their cause through abusing religion. He urged his former comrades to negotiate a treaty. Clearing himself of treachery, he maintained that he had led Devon's parliamentarians in good faith, declaring: "Twas not without excessive continued paines, that I had put that Tumultuous body into a serviceable posture in the field." He claimed that, while he lay wounded at Stratton, other parliamentarian commanders "that I am never likely to meet with in the field" fled to Exeter "to passe the time in making Aldermen, and women believe them valiant, whiles all the world knows the contrary." ${ }^{59}$ Diverting attention from his own inconstancy, he contrasted himself with former colleagues, whom he depicted as corrupted by urban and feminine influences and therefore incapable of masculine, military honor. The earl of Stamford had also charged Chudleigh's father, Sir

\footnotetext{
${ }^{54}$ Edward M. Furgol, "Sir John Urry (d.1650)," in ODNB; Gentles, The English Revolution and the Wars in the Three Kingdoms, 241.

${ }^{55}$ Sir Hugh Cholmley's memorial touching the battle of York, 1648, Bodleian Library (Bodl.), Oxford, Clarendon MS 23, fol. 153v; The history of the Scottish civil war by Henry Guthrie, Bishop of Dunkeld, 1637-49, Beinecke Rare Book and Manuscript Library, Yale University, Osborn Shelves, bl69, fol. 152; Binns, Memoirs and Memorials of Sir Hugh Cholmley, 137; Donagan, War in England, 49.

${ }^{56}$ Macray, The History of the Rebellion, 3:73-74.

${ }^{57}$ BL, TT E100(6), A Most Miraculous and Happy Victory Obtained by James Chudleigh Serjeant Major Generall of the Forces under the E. of Stamford, against Sir Ralph Hopton, 29 April (London, 1643), 3.

${ }^{58}$ Chudleigh claimed that he overawed the royalists "by beating in his six Scouts with three of ours and our shadows, we are left the onelie defence of this Countie": BL, TT E100(17): Speciall Passages and Certain Informations from Severall Places, 25 April to 2 May (London, 1643), 310-12.

${ }^{59}$ James Chudleigh, Serjeant Major James Chudleigh his Declaration to his Country-men (Oxford, 1643), $1-5$.
}

Thursday Dec 312009 09:46 AM JBS v49n2 85 BBS 
George Chudleigh, with cowardice and treachery, dealing an insufferable blow to Sir George's long-established reputation as a leading "patriot" and "father of his country" in Devon. ${ }^{60}$ By September 1643, Sir George Chudleigh had resigned his commission as lieutenant-general, withdrawn from parliamentarian allegiance, and claimed a royal pardon. By November, he had penned a self-defense "to satisfy his friends" that was quoted approvingly by Mercurius Aulicus. The London press responded in March 1644 by blasting his claim to constancy in a popular eightpage pamphlet, amusingly titled "the Grand Ambo-dexter." 61

These officers who returned from Ireland to desert Parliament for the king stressed their military skill and personal worth, and they expressed an aggrieved sense of betrayal or injured honor. Sir Richard Grenville remains their most notorious exemplar. Having served against the Irish rebels, he returned in 1643 and became lieutenant-general to the parliamentarian Sir William Waller. He joined the king at Oxford on 7 March 1644, with 36 troopers, a large consignment of soldiers' pay, and the parliamentarian plans for the spring campaign. Grenville's treachery was particularly flagrant because he had taken the Solemn League and Covenant and had reportedly pledged within the House of Commons that "he would never take up Arms against, but for the Parliament, and die in the defence of them with his last drop of blood." ${ }^{2}$ In response, London's press termed him "Turk," "infidel," "Judas," and "Skellum" for years afterwards. ${ }^{63}$ A confounded parliament ordered proclamations against him to be nailed to gibbets at Palace Yard and the Royal Exchange, leaving no doubt about his fate should he fall into parliamentary hands. Writing to Speaker Lenthall on 8 March, Grenville justified himself in a mocking and self-congratulatory tone. He declared that Parliament had slighted him by deliberately thwarting the settling of his legal affairs, accusing them of "a design to have a hold and engagement on me in a service I was so illsatisfied in." Then he argued that parliament's imposition of unlawful oaths, overstepping precedents, and confiscation of delinquents' estates had driven him to the king. If, as Clarendon maintained, Grenville later hinted that he planned this defection before he left Ireland, Grenville's claim that his parliamentarianism was a ruse to deceive the enemy was well calculated to mitigate his guilt and ingratiate himself with his new friends. ${ }^{64}$ On arriving in Devon, his letter urging the garrison of Plymouth to surrender explained his defection further. It insisted that he had wanted to keep out of the war, initially refusing parliament's "great tokens of favour" to serve them. It argued that he had been provoked into turning on Parliament, and it then fell into customary royalist arguments that parliamentarians had used religion as "the cloak of rebellion" and that they were directed by "sectaries of

\footnotetext{
${ }^{60}$ Mary Wolffe, Gentry Leaders in Peace and War: The Gentry Governors of Devon in the Early Seventeenth Century (Exeter, 1997), 158-64.

${ }^{61}$ BL, TT E75(37), Mercurius Aulicus, 29 October to 4 November (Oxford, 1643), 625; BL, TT E37(20), A Declaration Published in the County of Devon by that Grand Ambo-dexter, Sir George Chudleigh Baronet, 3-7.

${ }^{62}$ Keith Lindley and David Scott, eds., The Journal of Thomas Juxon, 1644-1647, Camden Society, 5th ser., 13 (1999), 48; BL, TT E250(16), A Perfect Diurnall of Some Passages in Parliament, 25 September to 2 October (London, 1643), 88.

${ }^{63}$ The term skellum had been used by Ben Jonson in 1611 and signified a rascal, scamp, scoundrel, or villain: Simpson and Weiner, The Oxford English Dictionary, 15:590.

${ }^{64}$ Miller, Sir Richard Grenville, 67-70.
}

Thursday Dec 312009 09:46 AM JBS v49n2 85 BBS 
infinite kinds which would not hear of a peace." Grenville reflected on having broken his Covenant oath by enclosing a tract entitled "The Iniquitye of the Covenant," but the parliamentarian governor ordered it to be burned in Plymouth marketplace by the common hangman. ${ }^{65}$

Thereafter, Grenville proved an energetic royalist commander, albeit with a tendency to inflame conflict within the royalist command. On 20 January 1646, he was arrested for refusing a commission from the Prince of Wales, and within a year he penned an immodest manuscript defense of his conduct that exaggerated his successes while blaming others for royalist setbacks. ${ }^{66}$ Despite his previous allegiance, this defense boldly declared his "sirvisses and intention was ever found faithfull to his mag[es]tie and to the contrary can noe man take him in any kind." ${ }^{97}$ He even complained to the prince's council that Lord Goring's men would rather "take to the enemyes party, then to bee Subiect to my course of discipline." ${ }^{\prime 8} \mathrm{He}$ presented himself as the victim of conspiratorial lords on the prince's council and a sufferer for unsullied loyalty. This was a very different image to his previous posturing as the champion of Cornish particularism in attempting to promote a separate negotiated peace between Cornwall and Parliament. ${ }^{69}$

Grenville penned another manuscript self-justification in January 1654, which again avoided mentioning his parliamentarian service. By then, Grenville had accused Clarendon of plotting with Cromwell, for which the exiled prince forbade Grenville from his presence. This affront robbed Grenville of the spiritual comforts of other exiled royalists, who at least enjoyed the consolation of reputations for constancy and integrity. Grenville remonstrated that his loyalty was "sufficiently tried" and that he was one of the crown's "faithfullest servants," adding: "I pray God it be not made a crime to be Loyall." He declared "all yt know me rightly, have known experience of my impartiality in service of his matie."70 In further protest, Grenville drafted an embittered manuscript autobiography that placed military service and loyalty to the crown at the heart of his professed concept of honor. ${ }^{71}$ It made the remarkable claim: "My former time spent hath binne as a Souldier, (as were all my Auncestors, since the Conquest of England, Anno 1066) ever constantly for services of the Crown of England." ${ }^{72}$ Espousing older, traditional notions of honor, he held that his pedigree, blood, and martial valor were

\footnotetext{
${ }^{65}$ Journal of the civil war by John Syms, 18 March 1643/4, BL, Add. MS 35297, fols. 31r-32v; BL, TT E47(1), A Continuation of the True Narration of the Most Observable Passages in and about Plymouth, 10 May (London, 1644), 9-12. The tract Grenville enclosed was almost certainly this one: BL, TT E36(10), The Iniquity of the Late Solemne League or Covenant, Discovered by Way of a Letter to a Gentleman Desiring Information upon the Poynt, 9 March (London, 1644).

66 "A Narrative of the affairs of the West since the defeat of the Erle of Essex at Listiddiell in Cornwell," c. 1647, Bodl., Clarendon MS 27, fols. 77-80.

${ }^{67}$ Ibid., fol. 79

${ }^{68}$ Ibid., fol. 3 .

${ }^{69}$ M. J. Stoyle, "The Last Refuge of a Scoundrel: Sir Richard Grenville and Cornish Particularism, 1644-46," Historical Research 71, no. 174 (February 1998): 49.

${ }^{70}$ Bedford et al., eds., Early Modern Autobiography, 9; Letter of Sir Richard Grenville to the marquis of Ormond, 4 January 1653-54, Bodl., Clarendon MS 47, fol. 242.

71 "Sir Richard Grenviles Single Defence Against all Aspersions (in the Power or Ayme) of Malignant Persons: And to Satisfie the Contrary," 28 January 1653-54, Bodl., Clarendon MS 47, fols. $312 \mathrm{r}-316 \mathrm{v}$.

${ }^{72}$ Ibid., fol. $312 \mathrm{r}$.
}

Thursday Dec 312009 09:46 AM JBS v49n2 85 BBS 
guarantors of loyalty. He recounted his military success against the Irish rebels in 1642 and claimed to have been invited by letters to return to serve the king in England. He completely passed over his service under Waller and again failed to explain how he joined the royalist cause. His final response was to adopt the tone of stoic forbearance and retirement that it was customary for the English gentry to employ during their moments of political failure. ${ }^{73} \mathrm{He}$ wrote that he would "make my peace with god and man: and to finde a quiet dying place in my native land: and never againe touch with any kinde of worldly affaires." Yet his bitterness overwhelmed his attempt at forbearance. Intimating that it was now too late for him to continue in royalist service, he echoed the earl of Strafford's reported disillusion with the Stuarts, quoting Psalm 146, "O put not your trust in Princes, nor in any Childe of man, for there is no helpe in him." Grenville's attachment to his lineage and martial honor left him ill-equipped to engage in a service suffering from contested command structures, imploding factional politics, and a collapsing war effort. His language of loyalty and service scarcely suppressed his vitriol, providing a thin veil for his inconstancy and the conditional nature of his allegiance.

This section examines the many ways in which print culture influenced the process of changing sides, making the meaning of defections increasingly public and contested. The proliferation of print in the 1640s provides a rich but problematic source for the self-representation of turncoats. Printed propaganda fueled the conflict and promoted infighting as both sides sought to capitalize on defections in their favor and revile those who deserted them. ${ }^{75}$ Gentlemen remained fashionably disdainful of cheap print and newsbooks, yet many recognized the importance of engaging with this powerful new arena for building and destroying reputations. Print increasingly shaped how notions of turncoating were constructed, while newsbooks' coverage of side-changers influenced the self-fashioning of turncoats and their expectations of future treatment. The press propagated much fictitious material in vilifying turncoats, turning individuals like Sir Richard Grenville into celebrated hate-figures for popular consumption. ${ }^{76}$ This shift to a public discourse raises methodological problems, as printed narratives adopted a variety of different forms, from character assassinations to self-defenses. Some turncoats addressed their self-justifications for a gentry audience, while others produced cheaper pamphlets for a more popular audience. On occasion, the turncoat's new masters might try to dictate what form these took or edit the text for polemical purposes, making it difficult to trace how far a turncoat's supposed self-narrative was actually being composed by others.

\footnotetext{
${ }^{73}$ Ann Hughes, "Men, the 'Public' and the 'Private' in the English Revolution," in Lake and Pincus, The Politics of the Public Sphere, 201-2.

74 "Sir Richard Grenviles Single Defence," Bodl., Clarendon MS 47, fol. 316r-v; Ronald G. Asch, "Thomas Wentworth, first earl of Strafford (1593-1641)," in ODNB.

${ }^{75}$ Jason Peacey, Politicians and Pamphleteers: Propaganda during the English Civil Wars and Interregnum (Aldershot, 2004), 27, 36

${ }^{76}$ Extracts from parliamentarian newspapers concerning the character and conduct of Sir Richard Grenville, 1643-57, BL, Stowe MS 768.
}

Thursday Dec 312009 09:46 AM JBS v49n2 85 BBS 
Publishing a declaration to justify changing sides was established practice by summer 1643. These texts ranged from a passage in an established serial newsbook to a fully dedicated pamphlet, and they were often published as soon as possible after the defection. ${ }^{77}$ Their production became obligatory as propagandists sought to maximize the damage that defections inflicted upon the enemy. For this purpose they tended to echo the propaganda of both sides. Declarations of parliamentarians who became royalists stressed how low-born social subversives, anarchy, and religious confusion dominated the parliamentary ranks, while their opposite counterparts trumpeted disgust at the Cessation in Ireland and the strength of popery at court.

Sergeant-Major Robert Kirle and Sir Edward Dering constitute telling examples of each. Kirle's lengthy declaration encompassed an eight-page pamphlet that claimed to publish a letter he had written to a friend at Windsor in February or March 1643, soon after his defection to Oxford. His avowed purpose in writing for a supposed parliamentarian audience was to "free myself from the imputation of dishonour, and undeceive others." He excused his previous parliamentarianism by claiming that, having recently returned from soldiering abroad, his ignorance of events led him unwittingly into Parliament's army. He argued that it was not necessity, ambition, or malice that motivated his defection, but rather "a perfect discovery of those false lights, that have hitherto misled me, and a deep apprehension of the horrour which attends the persevering in such errors." Then he stressed the link between religious plurality and social subversion that became the cornerstone of royalist propaganda: "Certaine I am, that all the Officers of no one Company were of the same Opinion what religion they fought for . . . . Some liked the Chaplain of the Regiment, another thought his Corporall preached better . . . and one would thinke, that every Company had been raised out of the severall Congregations of Amsterdam . . . if they cannot prove any of quality to be a Papist, yet as he is a Gentleman, he shall want grace; and that is title enough to possesse the estates of all that are more richer then themselves." ${ }^{78}$ How, if at all, Kirle explained this pamphlet when he returned to his parliamentary allegiance in September 1644 remains unknown, but his case illustrates how effectively selfdefenses could be turned to the purposes of partisan propaganda. ${ }^{79}$

This process grew more sophisticated as the war lengthened. Jason Peacey's extensive research on Sir Edward Dering has recently shown that, when Dering deserted Oxford for London in February 1644, Parliament forced him to issue a declaration explaining his defection. An ailing Sir Edward had wished to accept Parliament's offer of a pardon in order to return home to settle his personal affairs before he died. ${ }^{80} \mathrm{He}$ was granted liberty upon submitting an apologetic petition, but its contents were humiliatingly made public, and the county committee of his

\footnotetext{
${ }_{77}$ BL, TT E244(30), Mercurius Aulicus, 1-7 January (Oxford, 1643), 6.

${ }^{78}$ BL, TT E246(35), A Copy of a Letter Writ from Serjeant Major Kirle, to a Friend in Windsor (London, 1643), 2-3.

${ }^{79}$ Newman, Royalist Officers, 219; John Webb and T. W. Webb, eds., Memorials of the Civil War between Charles I and the Parliament of England as it affected Herefordshire and the Adjacent Counties, 2 vols. (London, 1879), 2:98, 238, 350-53; BL, TT E339(9), The Gallant Siege of the Parliament's Forces before Ragland Castle, 30 May (London, 1646).

${ }^{80}$ Jacqueline Eales, Community and Disunity: Kent and the English Civil Wars, 1640-1649 (Faversham, 2001), 15.
}

Thursday Dec 312009 09:46 AM JBS v49n2 85 BBS 
native Kent insisted he should publicly repudiate royalism in "no volume, but an epitome . . . a little pamphlet, which will better sink into the common people's brain than any long volume." An unenthusiastic Dering eventually promised "the pamphlet you command shall go out sudden and unpolished" and that it would "be a piece of a penny, fit . . . for the vulgar." ${ }^{81}$ The pamphlet was published on 1 April, and it pleased parliament by trumpeting the key claims of parliamentary propaganda to a mass audience. Dering expressed disgust at Catholic officers dominating the king and abhorrence of the Cessation in Ireland. Dering's condemnation of the Oxford Parliament as "an anti-Parliament" was conveniently timely, while his tirade against Laudian-popish ceremonies and the "Dionysian Orgy" of organ music at Oxford was surely calculated to appeal to the godly: "One single groan in the Spirit, is worth the Diapason of all the Church-Musick in the world." 82

Despite attempts at a constancy narrative, Dering admitted to a genuine conversion, comparing himself with Saint Paul, "from a Persecuter, I was made a Convert." He joined the king in summer 1642 as "the most unwilling man that ever went," even making the dubious claim that he had advised the king to return to Westminster with just forty servants accompanying him. Dering stressed that he returned out of choice, not compulsion, and "professing my self very sorry for bearing Arms against the Parliament." 83 This was a godsend for parliamentary propaganda. Dering had been a vocal member of Parliament, renowned for courting popularity by circulating his speeches. It was widely anticipated that reports of his defection would precipitate other royalists to change sides or withdraw their allegiance. ${ }^{84}$ Indeed, Sir Anthony Ashley Cooper was among several who changed sides soon after, surrendering himself to the parliamentary garrison at Hurst castle on 24 February 1644. Like Dering before him, he emphasized political principles before his personal interests, remarking that the influence of Catholics at court and the Cessation in Ireland were "destructive to religion and state." Ashley Cooper had resigned his royalist commissions well before changing sides, and he maintained that he had therefore not acted dishonorably or been unfaithful to the king. Parliament evidently considered his principled conversion genuine; by August 1644, he was commissioned as parliamentarian field marshal-general in Dorset, remaining a loyal and energetic commander thereafter. ${ }^{85}$

\footnotetext{
${ }^{81}$ Jason Peacey, "Popularity and the Politician: Sir Edward Dering and the Public, 1640-1644," paper presented at the Early Modern British History Seminar, University of Cambridge, 2007.

${ }^{82}$ BL, TT E40(5): A Declaration by Sir Edward Dering Knight and Baronet, 1 April (London, 1644), 8-11.

${ }^{83}$ Ibid., 2-3, 6, 7-8.

${ }^{84}$ C. H. Firth, ed., The Memoirs of Edmund Ludlow, Lientenant General of the Horse in the Army of the Commonwealth of England, 1625-1672, 2 vols. (Oxford, 1894), 1:86; Francis Bickley, ed., Report on the Manuscripts of the Late Reginald Rawdon Hastings, Esq., TNA: Historical Manuscripts Commission (HMC), 78, 4 vols. (London, 1928-47), 2:122; BL, TT E32(1), A Continuation of Certain Speciall and Remarkable Passages Informed to the Parliament, 1-8 February (London, 1644), 7; BL, TT E32(11), The Parliament Scout Communicating his Intelligence to the Kingdome, 2-9 February (London, 1644), 278-80.

${ }^{85}$ Tim Harris, "Anthony Ashley Cooper (1621-1683)," in ODNB; Patrick Little, "Four Dorset Turncoats," paper delivered at conference on the Civil War at the Dorset Record Office, Dorchester, 2002.
}

Thursday Dec 312009 09:46 AM JBS v49n2 85 BBS 
This penultimate section of the article examines the self-fashioning of the governors of Scarborough and Hull garrisons, Sir Hugh Cholmley and the Hothams, respectively. Cholmley's memoirs and memorials set about justifying his defection in a much different way from the pamphlets and newsbooks discussed above. Cholmley wrote these manuscript memoirs in the changed circumstances of 1656 , and the passage of time allowed greater opportunity for refashioning and selfdeception. ${ }^{86}$ Kevin Sharpe and Steven Zwicker have discussed how the writers of such memoirs were concerned to produce exemplary accounts, "written for use" and designed as a counsel and guide for others. ${ }^{87}$ Cholmley addressed his memoirs to his sons for the defense of his good name. They made several false claims, including that, when he changed sides in March 1643, the whole garrison of Scarborough "was immediately settled for the King without the least mutiny or disturbance." ${ }^{88}$ He remained anxious that posterity would regard him as inconstant. He maintained that he did not break his trust with Parliament. Instead, it had broken its trust with him by altering the grounds of the war, failing to supply him properly, and allowing his name to be slandered in London. His memoirs claimed that his motives were not "for any perticuler ends of my owne, but merely to performe the duty and alleagance I owed to my Soveraigne, and which I did in such away as was with out any deminution of my honour either as a gentleman or souldier." 89

During 1648 Cholmley had written an earlier retrospective justification for Clarendon entitled "Memorialls tuching Scarbrough." This prose sought to explain his former parliamentarianism as having arisen from an "apprehension that persons ill affected to the peace of the kingdome did intrude themselves into imployment." He contended that, by undertaking the governorship of Scarborough, he kept out more dangerous alternatives, while his more impartial disposition enabled him to promote peace from a position of armed strength. He claimed that his Protestation and allegiance oaths required him to defend the king and that he twice urged Speaker Lenthall to negotiate a peace treaty, lamenting that the "kings faire and reasonable propositions" went unheeded..$^{90}$ Cholmley had indeed complained to Lenthall, and when the Commons responded by ordering him to quit Scarborough, he refused..$^{91}$ Instead, he traveled in disguise to York, on 20 March 1643, to secretly negotiate his defection with the queen. One of his initial conditions, later overtaken by events, was that he be granted three weeks to return his commission to Essex so that when he turned royalist he might not be charged with betraying his trust. ${ }^{92}$

${ }^{86}$ Glaser, The Creation of the Self, 5 .

${ }^{87}$ Sharpe and Zwicker, Writing Lives, vi, 4, 13, 19.

${ }^{88}$ Binns, Memoirs and Memorials of Sir Hugh Cholmley, 144.

${ }^{89}$ Ibid., 105

${ }^{90}$ Ibid., 143.

${ }^{91}$ For Cholmley's complaint to Speaker Lenthall, see TNA: HMC, Portland MSS, 29, 13th Report, appendix, part 1 (London, 1891), vol. 1, 90; York Minster Library (YML), Civil War Tract (CWT), 43-01-18, Newes from Yorke. Being a True Relation of the Proceedings of Sir Hugh Cholmley (London, 1643).

${ }_{92}$ Binns, Memoirs and Memorials of Sir Hugh Cholmley, 142-43. 
Like Chudleigh and Grenville, Cholmley magnified the injuries his honor received from Parliament. In December 1642, he was chastised in Parliament for disobeying Lord Fairfax's orders, and by January 1643, he bitterly complained of his treatment in the press, warning Lenthall that "my former actions did never deserve those representations of them which were in print, nor any belief of them." ${ }^{93}$ In March, he lamented that Parliament had slighted him by not sending him sufficient supplies. ${ }^{94}$ Cholmley's sensitivity was partly due to his upbringing. He admitted that his father was of a "haughty sperret and chollericke," swore too much, and was prone to duels and rude behavior toward his servants and the country people. His father struck a gentleman in Star Chamber, and Sir Hugh himself struck down a trained bandsman for insolence in 1639. ${ }^{95} \mathrm{~A}$ close attention to lineage, reputation, and local standing shaped Cholmley's notion of honor. For instance, his pew at Whitby, which "completely straddles the chancel arch," has been described as an "incredibly vulgar" display of status. ${ }^{96}$

Cholmley's representation to his sons of selfless cavalier loyalty is less than convincing. His defection was dictated by the local military situation, for he sought to prevent Scarborough being besieged. ${ }^{97}$ If the northern royalist army was not so large and threatening to his estates, Cholmley's royalism may have been less forthcoming. Furthermore, his honor was soon questioned by comrades who had deserted. Fearing to come abroad, his terms with the queen insisted that he remain Scarborough's governor. He surrounded himself with servants armed with pistols and almost came to blows with his officers, at least six of whom deserted him with about one hundred troopers. In endeavoring to dissuade him from changing sides, one of his captains claimed to have warned him "what a dishonour it would be to himselfe, and what a stain to his posterity." 98

Cholmley was ordered to be impeached for high treason in the Commons on 2 April 1643. In October 1645, his exemption from pardon was proposed. ${ }^{99}$ The press, whose invective against him was vicious, amplified the condemnation. $\mathrm{He}$ was nicknamed "Judas Cholmley," a "base treacherous (Apostate)," who "deserves not the name of a gentleman," and he was accused of putting Whitby civilians to the sword. ${ }^{100}$ Compelled by this savaging, Cholmley crafted a self-image of personal

${ }^{93}$ Journals of the House of Commons, 2:893; Letter of Sir Hugh Cholmley to William Lenthall, 16 January 1642-43, TNA: HMC, Portland MSS, HMC, 29, 13th Report, appendix, part 1, vol. 1, 90; Parliamentary journal of Sir Simonds D'Ewes, 16 February 1642-43, BL, Harl. MS 164, fol. 298r.

${ }^{94} \mathrm{BL}$, TT E95(9), A True and Exact Relation of all the Proceedings of Sir Hugh Cholmley's Revolt, 7 April (London, 1643), 4.

${ }^{95}$ Binns, Memoirs and Memorials of Sir Hugh Cholmley, 70-71, 99.

${ }^{96}$ Felicity Heal and Clive Holmes, The Gentry in England and Wales, 1500-1700 (London, 1994), 338.

${ }^{97}$ Jack Binns, "A Place of Great Importance": Scarborough in the Civil Wars (Preston, 1996), 96.

${ }^{98}$ Disbursements to the garrison at Beverley, 1642-3, TNA: PRO, SP $28 / 138 / 3$; BL, TT E95(9), A True and Exact Relation, 5-7.

${ }_{99}$ Parliamentary journal of Lawrence Whitacre, 2 April 1643, BL, Add. MS 31116, fol. 40r; Parliamentary journal of Sir Simonds D'Ewes, 3 April 1643, BL, Harl. MS 164, fol. 351r; Parliamentary journal of Sir Simonds D'Ewes, 23 October 1645, BL, Harl. MS 166, fol. 271r.

${ }^{100}$ BL, TT E252(34), A Perfect Diurnall, 11-18 March (London, 1644), 259; BL, TT E270(33), The Scottish Dove, 21-28 February (London, 1645), 556; BL, TT E95(2), The Kingdomes Weekly Intelligencer, 28 March-4 April (London, 1643), 110. 
constancy and injured honor, beset by the inconstancy of his former cause and comrades. This constitutes a recurrent notion among sympathetic representations of side-changing. His protestations persuaded Clarendon, who clearly admired him, and even Gardiner, who compared him favorably with the Hothams, saying he appeared "to have had the nobler nature, and to have been actuated by the purer motives." $" 101$

Our final case study for the self-fashioning of turncoats examines the correspondence of disaffected officers with enemy commanders, a perennial fear of leaders on both sides. A large number of such letters survive between the earl of Newcastle and the two greatest failed turncoats of the war: Sir John Hotham, Parliament's governor of Hull, and his eldest son, deputy governor, and namesake Lieutenant-General John Hotham. Their conspicuous role in denying the king entrance to Hull in April 1642 made them national figures, but their parliamentarianism cooled thereafter as, like Cholmley, their estates were threatened by the earl of Newcastle's large royalist army. Fearful of religious radicalism and social subversives among the West Riding's populous clothing districts and angered at the eminence of their rivals the Fairfaxes, the younger Hotham entered into a frequent, friendly correspondence with Newcastle from December 1642. He eventually pledged to Newcastle that he would defect at an opportune moment and bring with him his father, Hull, Beverley, and Lincoln, along with disaffected parliamentarians in Lincolnshire and the East Riding. ${ }^{102}$

In these letters the younger Hotham presented himself to Newcastle as trustworthy, honest, constant, and an effective military commander who might be brought to change sides if Parliament should err: "I am very sorry you should ever harbour such an opinion of me as to thinke that any motive whatsoever could ever move me to betray the publicke trust I have undertaken. Unless they had unquestionably fal[le]n from principles of honor and honesty I could never have satisfied my selfe, but I should have bene the scorne and by word of every boy in the streete." 103 Although he affected to be disdainful of heeding rumor and gossip among the common sort, he nevertheless remained notoriously sensitive about what was being said or might be said about him. He warned Newcastle, on 3 April 1643, that Cholmley's defection had "drawne such a jealousy upon me and our people talk at large." 104 Cholmley later remarked that the Hothams delayed defecting because they were waiting upon events and the result of the

${ }^{101}$ Gardiner, History of the Great Civil War, 1:105.

${ }^{102}$ Letters of John Hotham to the earl of Newcastle, 18 December 1642, 9 January 1642-43, 12 February 1642-43, 18 and 26 April 1643, HHC: HUA, Hotham MS, DDHO/1/14, 18, 20, 28-29; Letters of John Hotham to the earl of Newcastle, 20, 26 and 30 April 1643, Bodl., Tanner MS 62, fols. 71, 83, 90; Letters of John Hotham to the earl of Newcastle, 9 and 15 January $1642-43,11$ and 12 February $1642-43,2,9,11$ and 22 March 1642-43, and letter of Sir John Hotham to William Lenthall, 17 March 1642-43, BL, Add. MS 32096, fols. 248-51; John Hotham to the earl of Newcastle, 19 and 27 December 1642, 2 and 15 January 1642-43, 11 and 12 February 1642-43, 2 March 1642-43, 30 March 1643, 1, 3, 14 and 18 April 1643, 4 and 5 May 1643, TNA: HMC, Portland MSS, 29, 13th Report, appendix, part 1, vol. 1, 80-84, 89, 99, 109, and supplement, 699-707.

${ }^{103}$ Letter of John Hotham to the earl of Newcastle, 1 April 1643, HHC: HUA, Hotham MS, $\mathrm{DDHO} / 1 / 27$.

${ }^{104}$ Letters of John Hotham to the earl of Newcastle, 3 and 26 April 1643, HHC: HUA, Hotham MS, DDHO/1/12, 29.

Thursday Dec 312009 09:46 AM JBS v49n2 85 BBS 
siege of Reading. The younger Hotham knew of such rumors, for he pledged to Newcastle, on 4 May 1643, "I am as much your servant as ever, and twenty such businesses as Reading shall make no alteration." ${ }^{105} \mathrm{He}$ indicated his desire to change sides but to do so in such a way "as not to bring upon me the odious name of knavery." He held out the hope that Parliament's mistreatment of him would permit a change of sides without staining his honor, which he remarked was "like a woman's honesty, not to be repaired if once toucht." Meanwhile he sought to ingratiate himself by warning Newcastle that he was mocked at court by Lady Cornwallis, who said, "that you were a sweet General, lay in bed until eleven o'clock and combed till 12, then came to the Queen, and so the work was done, and that General King did all the business." He warned Newcastle, "You can expect nothing at court, truly the women rule all."106 By pointing to the inversion of gender roles at court, he shrewdly appealed to Newcastle's frustration with gossips jealous of his success in raising a large army. Here the concept of women's unnatural engagement in high politics blended with notions of secrecy, intrigue, and deception as feminine attributes. ${ }^{107}$ The younger Hotham contrasted this with the virtues of the open, masculine friendship, personal loyalty, and constancy that he offered the earl. His repeated self-justificatory references to his honor strung Newcastle along and were intended to protect the Hotham estates from royalist soldiers, until, prepared with strong arguments against having broken their trust, his family was ready to defect. Hotham knew well that, since his father refused the king at Hull, they would need to defect spectacularly by drawing a large force and territory into royalist control. This procrastination led to widespread speculation about the betrayal of Hull weeks before their final arrest on 29 June $1643 .{ }^{108}$ They remained untried for seventeen months, but Sir John Hotham's defense for his trial at the Guildhall in December 1644 provides another excellent source for a turncoat's self-fashioning.

Written to save his life, the dramatic language of the defense magnified Sir John's former services in securing Hull and emphasized the danger to his person. As in other contemporary prison writings, Sir John sought to validate his conduct and overturn the suspicions that led to his confinement. ${ }^{109}$ Referring to his refusal of the king, Sir John declared he did not seek "to have a part to play unpresidented by any," adding, "I satt downe with joy under the name and hazard of a Traytor." $\mathrm{He}$ argued that his "single endeavours" had raised, paid, and maintained over 3,000 men. He passed off his correspondence with Newcastle as a "craft of treaties" he learned from Count Mansfeldt in Germany to prevent Newcastle from wasting the East Riding, upon whose contributions Sir John relied to maintain his garrisons.

\footnotetext{
${ }^{105}$ Hugh Cholmley, "Some Observations and Memorials Touching the Hothams," in State Papers Collected by Edward, Earl of Clarendon, 3 vols. (Oxford, 1767-86), 2:182-83; TNA: HMC, Portland MSS, 29, 13th Report, appendix, part 1, vol. 1, and supplement, 707.

${ }^{106}$ Letter of John Hotham to the earl of Newcastle, 3 April 1643, HHC: HUA, Hotham MS, DDHO/1/12; Letter of John Hotham to the earl of Newcastle, 30 March 1643, TNA: HMC, Portland MSS, 29, 13th Report, appendix, part 1, vol. 1, 109, and supplement, 701.

${ }^{107}$ Sara Heller Mendelson and Patricia Crawford, Women in Early Modern England, 1550-1720 (Oxford, 1998), 403; Hughes, "Men, the 'Public' and the 'Private' in the English Revolution," in Lake and Pincus, The Politics of the Public Sphere, 196, $208 \mathrm{n}$.

${ }^{108}$ John Tickell, History of the Town and County of Kingston-upon-Hull (Hull, 1796), 465-68.

${ }^{109}$ Dosia Reichardt, "The Constitution of Narrative Identity in Seventeenth-Century Prison Writing," in Bedford et al., Early Modern Autobiography, 119-20.
}

Thursday Dec 312009 09:46 AM JBS v49n2 85 BBS 
He claimed that there was no evidence of his involvement in a plot to betray Hull, that he had been arrested and imprisoned without charge, and that his trial by martial law was illegal. Sir John also criticized the "ill management," and "backwardnesse" of the Fairfaxes for having brokered a treaty of neutrality in September 1642 , and for failing to reinforce him to contest the Queen's passage to York in February 1643. ${ }^{110}$

Yet, despite this forceful defense, what doomed father and son was their shared tendency, common among turncoats, to respond impulsively to perceived slights. When the younger Hotham returned to Hull after escaping from his first arrest at Nottingham, Sir John Hotham procured the signatures of his council of war to a strikingly peremptory letter to Parliament, demanding that Cromwell and his "Anabaptist rogues" "be delivered to justice" for causing his son's wrongful imprisonment. The letter prepared the ground for their long-considered defection, stating explicitly that their sense of injury freed them from the obligations of their former allegiance:

There is nothing in this world, next to their duty to God Almighty, dearer to men of honour than their reputations; neither is there any thing that falls out with more regret to them, than to have that violated by those whom they esteem their friends, and of whom, they conceive, they have had just right to expect other dealings. This letter is occasioned by the most unjust and perfidious wrong offered to one of our society here, which, as we conceive, was ever put on any man; and, we are further persuaded, that no age or history can produce the like example: and truly, it gives us all just cause to look to our own conditions, who are by the king esteemed traitors; and if we shall be subject to be abused by such mischievous instruments as these are, who have been the cause of this gentleman's wrong, we certainly remain in a sad condition; and, we think, we shall be excused before God and man, to do the best we can for our own preservation. ${ }^{111}$

The Hothams stressed blood, pedigree, and lineage in their ideas about honor because their capacious kinship network, provided by eight ill-fated wives, related them to all the East Riding's leading parliamentarians. ${ }^{12}$ Since the Hothams could boast an unbroken lineage of succession from father to son since the twelfth century, it was hardly surprising that their concept of honor stressed pedigree. Such continuity of lineage was held to prove a family's virtue, since longer, purer pedigrees concentrated levels of noble blood. ${ }^{113}$ Partly due to this, they had grown notoriously sensitive to perceived slights. On the scaffold, Sir John admitted that

\footnotetext{
${ }^{110}$ Draft defense of Sir John Hotham, c. November 1644, HHC: HUA, Hotham MS, DDHO/ 1/34; Legal defense of Sir John Hotham, c. November 1644, HHC: HUA, Hotham MS, DDHO/ 1/35; Defense notes and interrogatories, December 1644, HHC: HUA, DDHO/1/40; Basil N. Reckitt, Charles the First and Hull, 1639-1645 (Howden, 1988), appendix 2, 119-28.

${ }^{111}$ Tickell, History of the Town and County of Kingston-upon-Hull, 458-60.

${ }^{112}$ Bulstrode Whitelocke, Memorials of English Affairs from the Beginning of the Reign of Charles I to the Happy Restoration of King Charles II, 4 vols. (Oxford, 1853), 1:206; Macray, The History of the Rebellion, 3:526-29; Daniel Parsons, ed., The Diary of Sir Henry Slingsby of Scriven, Bart (London, 1836), 92; William Dugdale, The Visitation of the County of Yorke, Surtees Society, 36 (1859), 386.

${ }^{113}$ Cust, "Catholicism, Antiquarianism and Gentry Honour," 49; Anna Maria Diana Wilhelmina Stirling, The Hothams: Being the Chronicles of the Hothams of Scorborough and South Dalton from their Hitherto Unpublished Family Papers, 2 vols. (London, 1918), 1:21.
}

Thursday Dec 312009 09:46 AM JBS v49n2 85 BBS 
for "rash words, anger and such things, no man has been more guilty." 114 Strafford considered Sir John was "extreme sensible of honour, and discourtesies perhaps a little overmuch." In 1642, John Hampden sent placatory letters reassuring Hotham that his honesty remained unquestioned. ${ }^{115}$ Their aggressive sense of honor left them ill-equipped to obey commands from Lord Fairfax or accept Parliament's failure to send money and supplies. They also considered their Yorkshire baronetcy equal or superior to Fairfax's Scottish barony. A letter among the Hotham papers concerning John Hotham and Lord Fairfax lamented of the "unhappy difference twixt men soe equally worth." 116 Only a family particularly strident about its status would acclaim an esquire the equal of a baron, while Sir John warned the Fairfaxes to "give not law to those from whom you ought to receive." 117 The hostility toward the Fairfaxes in Sir John's defense also reflected how the Hothams' trials became entwined with factional power struggles at Westminster over new-modeling the parliamentary armies. ${ }^{118}$

From the wavering of county magnates like Sir John Hotham to the businesslike transactions of career soldiers like Sir John Urry, gentlemen changed sides for a variety of reasons. They communicated their defections in widely differing ways to vindicate themselves and establish the "truth" of their actions. It remains difficult to disentangle their self-interest from political loyalties, and contemporaries may not always have envisioned such distinctions. Yet, despite these differences, several collective similarities emerge from the individual cases discussed. Few defections occurred among godly parliamentarians, while the Hothams, Chudleigh, Cholmley, Grenville, and Urry were hardly noted for attachment to Puritans. Although turncoats had been brought up with civic humanist notions of serving the public, which some of them vocalized in their self-justificatory narratives, many defections appear to have been grounded upon older concepts of honor, placing lineage, pedigree, and martial values at the heart of the defectors' sense of self-worth. This supports Richard Cust's arguments that the early Stuart gentry were adept at employing a variety of concepts of honor in their self-representation to meet changing needs, occasions, and audiences. For example, the composition narratives tend to emphasize their faithfulness to the parliamentary cause from the outset, propaganda conversion narratives focused most on the alienating features of the enemy, and memoirs and autobiographies for posterity were most inclined to stress principle and constancy.

\footnotetext{
${ }^{114}$ John Morrill, The Nature of the English Revolution (London, 1993), 184; Heal and Holmes, The Gentry in England and Wales, 171; Stirling, The Hothams, 1:96-97.

${ }^{115}$ Philip Saltmarshe, History and Chartulary of the Hothams of Scorborough in the East Riding of Yorkshire, 1100-1700 (York, 1914), 112; Letter of John Hampden to Sir John Hotham, 4 October 1642, HHC: HUA, Hotham MS, DDHO/1/8.

${ }^{116}$ Draft letter concerning John Hotham and the war in Yorkshire, n.d., 1643, HHC: HUA, Hotham MS, DDHO/1/60.

${ }^{117}$ YML, CWT, 1642-43(2), Reasons Why Sir John Hotham, Trusted by the Parliament, Cannot in Honour Agree to the Treaty of Pacification made by some Gentlemen of York-shire at Rothwell, 29 September (London, 1642), 2, 8.

${ }^{118}$ Andrew Hopper, "Black Tom": Sir Thomas Fairfax and the English Revolution (Manchester, 2007), 60-62.
}

Thursday Dec 312009 09:46 AM JBS v49n2 85 BBS 
The status-obsessed nature of the English gentry may well have inclined those most sensitive about perceived slights to be more prone to side-changing. ${ }^{119}$ Those more temperamental about standing and rank appear more conditional in their allegiance and less able to fully commit to serving a cause. It is revealing just how many turncoats argued that they were slighted by their comrades before they changed sides. Defections were rarely hasty decisions but more usually the culmination of a growing sense of disillusionment. Although both sides developed mechanisms for redressing slighted honor and containing factional conflict, when these failed, changing sides became the ultimate sanction for those snubbed by colleagues or marginalized by internecine politics. ${ }^{120}$ As Patrick Little has observed, it was often "a reaction against the old masters, not a sudden burst of enthusiasm for the new ones." ${ }^{121}$ However, turncoats nearly always claimed to be following their consciences and therefore to be acting with due principle and constancy. Sensitive about defending reputations for their descendants and posterity, they fashioned their retrospective narratives of constancy through selective memory and avoidance of compromising details. Some resigned their commands weeks before defecting to protect themselves from charges of betraying their trust. Many professed or experienced genuine political conversions, seeking to play down the significance or explain away the reasons for their former allegiance. Others displaced the slur of inconstancy onto former comrades; it was not the turncoat but they who had changed. This confirms that, by the 1640s, the English gentry had grown remarkably adept at projecting a variety of self-representations for different purposes and audiences.

Although primary sources such as Clarendon and recent historians such as Mark Stoyle agree that defectors were scorned, this reaction was not universal. Some defectors remained true to their new allegiance in the face of unfavorable subsequent circumstances, so we should be wary of discountenancing all declarations of principle in self-justificatory statements. Neither should all turncoats be interpreted as cynical political opportunists; many defections followed tortuous and ongoing dilemmas of conflicting loyalties. Most of those parliamentarians who joined the king in 1643 stood by their decisions, and their steadfast royalism thereafter remains striking. ${ }^{122}$ Some defectors became valued and trusted by their new comrades, and Barbara Donagan has argued that, despite many being executed, "the record is dotted with turncoats who survived and prospered." ${ }^{123}$ Those able to persuade themselves and enough others that they changed sides from conscience might retain their own sense of honor and public reputation despite bitter condemnations from those they deserted. ${ }^{124}$

\footnotetext{
${ }^{119}$ Hopper, "Fitted for Desperation," 153-54.

${ }^{120}$ Ann Hughes, "The King, the Parliament, and the Localities during the English Civil War," Journal of British Studies 24, no. 2 (April 1985): 259-63; Ian Atherton, "Royalist Finances in the English Civil War: The Case of Lichfield Garrison, 1643-45," Midland History 33, no. 1 (Spring 2008): 66-67.

${ }^{121}$ Little, "Four Dorset Turncoats."

${ }^{122}$ Newman, The Old Service, 40-41, 121.

${ }^{123}$ Prominent examples included in the $O D N B$ are Sir Anthony Ashley Cooper, Bussy Mansell, Sir Edward Massey, Sir Trevor Williams, and Henry Mordaunt, second earl of Peterborough.

${ }^{124}$ Donagan, "The Web of Honour," 382-83.
} 